\title{
Index by author
}

\section{Volumes 1 to 3:}

Boden, Ian, 'Time to light up the NBC airwaves,' 2:1:47-49. Cass, Philip, 'Dilemma for Fiji media and the constitution,' 2:1:69-72.

Than, Sir Julius, 'Serve truth with development news,' 2: 1:78-82. Zronau, Peter, 'Self-censorship: The most insidious gag,' 2:1:11-15. Centurion, Fr Diosnel, 'The prophetic role of Christian media.'

$1: 1: 48-57$.

Jixit, Kunda, 'Now the negative news from paradise,' $2: 1: 116-118$. Jusava, Gabriel, 'A blurred and distorted view of PNG,' 2:1:90-94. Ferea, William, 'The death penalty: A flawed debate,' 2:1:62-67. Jemo, Rev Oria, 'PNG's new information order (in waiting),

\section{1:1:38-47.}

oku, Harlyne, 'The Times of Papua New Guinea: An investigative tradition,' 2:1:8-10.

Sama, Nimo, 'Neville Togarewa: A scoop in the jungle,' 2:1:124-126.

'uasi, Sophie, 'Abby Yadi: From fish to business,' 2:1:127-130.

- 'Wendy Bacon: A bullet and an orchid,' 2:1:120-122. Aaino, Sir Charles, 'People, news and government,' 2:1:84-89. Aanassah, Kiery, 'Bleak media scenarios confront Vanuatu,' 2:1:73-76.

Jalangu, Walter, 'Investigative journalism in Melanesia: Is it needed?', 2:1:16-22.

Jonggorr, John, 'The copyright law and PNG,' 2:1:58-61.

hasio, Campion, Ting Ting Bilong Mi, collection of editorial cartoons, 3:1:13-97.

eni, Ekonia, 'Cat-and-mouse over the French nukes,' 2:1:140-142. inder, James, 'Open season for snipes at the media pack', 2:1:37-39. - 'The "untouchables" era', 1:1:6-8. ichards, Deborah, 'Bush Bugarup', 1:1:30-36. obie, David, 'A photographer's date with a nuclear death,' 2:1:132-139. 
Robie, David, 'Attacks on the press', 2:1:41-45.

- 'Ethical dilemmas for the PNG media', 1:1:59-70.

- 'Introduction: Ting Ting Bilong Mi,' collection of Campion Ohasio editorial cartoons, 3:1:7-12.

- 'Share the whole vision, good news and bad,' 2:1:95-102.

- 'When the deadline becomes death', 1:1:11-15.

Solomon, Anna, 'Women in the media', 1:1:23-29.

Sorariba Nash, 'A free ride to propaganda', 1:1:73-87.

- 'International news flow cooperative study,' 2:1:50-55.

- 'Regional conflicts: Getting both sides,' 2: 1:103-112.

The Review (Fiji), 'Rabuka and the reporter', 1:1:20-22.

The Times of Papua New Guinea, Editorial: 'Bougainville: Six years too long', 1:1:92-93.

Togarewa, Neville, 'The NBC islands gag', 1:1:16-19.

Vatsikopoulos, Helen, 'PNG: Under the spell,' 2:1:24-36.

Waibauru, Jessie, 'A frog's head, old ashtrays and student politics' 1:1:88-91.

\section{Forum:}

Chang, Henry, 'Give "new kid on the block" a fair chance,' 2:1:144 146.

Cronau, Peter, 'Tabloid transition,' 2:1:147.

Ingram, David, 'Ancient Remingtons,' 2: 1;147.

Layton, Suzanna, 'World-class education,' 2: 1:147.

Obi, Margaret, 'New message without fear or favour', 1:1:95.

\section{Reviews:}

Bourne, Richard, News on a Knife-edge: Gemini Journalism and a Global Agenda. London:John Libbey, 1995. Reviewed by David Robie. 2:1:161-163.

Fogg, Christine, Mastering the Maze: How to Use Your Library to Break the Information Barrier. Sydney: Australian Centre for Inde pendent Journalism, 1994. Reportage.

Gunn, Geoffrey, A Critical View of Western Journalism and Scholar ship on East Timor. Manila: Journal of Contemporary Asia Pub lishers, 1994. David Robie. 1:1:97-98.

Pacific Journalism Review. Port Moresby: South Pacific Centre for Communication and Information in Development (SPCenCIID), 1994. Peter Miva, 2:1:151-152. 
Rannells, Jackson, PNG: A Fact Bookon Modern Papua New Guinea. Melbourne: Oxford University Press, 1995. David Robie. 2:1:152154.

Robie, David, Blood on their Banner: Nationalist Struggles in the South Pacific. London: Zed Press, 1989. Alan Robson. 2:1:157158.

- (ed) Nius Bilong Pasifik: Mass Media in the Pacific. Port Moresby: University of PNG Press, 1995. Assoc Prof Robbie Robertson. $2: 1: 148-150$.

Schoell, Hans-Martin, Development and Environment in Papua New Guinea: An Overview. Goroka: Melanesian Institute, 1994. Peter Miva.

Spelliscy, Jill and Gerald B. Sperling (eds),Whose Story? Reporting the Developing World After the Cold War, Calgary, Canada:

Detselig Enterprises, 1993. David Robie. 1:1:96-97.

Ward, Ian, Politics of the Media. Melbourne: Macmillan Educational Publishers, 1995. David Robie. 2:1:154-156. 